\title{
PIDANA DALAM MEMBENTUK KETERATURAN SOSIAL (TINJAUAN SOSIOLOGIS)
}

\author{
Oleh : KUKUN ABDUL SYAKUR MUNAWAR ${ }^{*}$ \\ (akoe kun@yahoo.co.id)
}

\begin{abstract}
Crimes often cause problems, the emergence of recidivists, and the existence of professional crimes are complicated problems that continue to get sorortan and attention of law enforcement officers. Crimes that occur in the community and prevention efforts continue to be a conversation to find a solution to the problem of crime. But it must be realized that those who commit crimes are also people like all of us and on the other hand crime must continue to be addressed because it brings insecurity in society. One important principle in this matter is that "efforts to prevent crime must take precedence over efforts to improve criminals. Crime has become a universal phenomenon, meaning that there is no society without crime. In the beginning, crime was caused by poverty, so that in a society experiencing a shortage of natural resources, crime will flourish in that society. However, over time crime is also caused by prosperity. To continue to press that criminal acts do not continue to be repeated, it must be done in various ways either in a strict manner or by enforcing repressive and preventive criminal law.
\end{abstract}

Keywords: Crime, Criminal Law, Criminality

\begin{abstract}
Abstrak
Kejahatan kerap kali menimbulkan masalah, munculnya residivis, dan adanya kejahatan yang bersifat professional merupakan masalah pelik yang terus mendapat sorortan dan perhatian aparat penegak hukum. Kejahatan yang terjadi dalam masyarakat dan upaya pencegahannya terus menjadi perbincangan untuk dicarikan pemecahan pokok persoalan kejahatan itu. Namun harus disadari bahwa yang melakukan kejahatan itu juga orang seperti kita semua dan disisi lain kejahatan harus terus ditanggulangi karena mendatangkan ketidak tentraman dalam masyarakat. Salah satu asas penting dalam masalah ini ialah "usaha-usaha mencegah kejahatan harus lebih diutamakan dari usaha memperbaiki para penjahat. Kejahatan telah menjadi fenomena yang universal, artinya tidak ada masyarakat tanpa kejahatan. Pada mulanya kejahatan disebabkan oleh faktor kemiskinan, dengan demikian dalam masyarakat yang mengalami kekurangan sumber daya alam, kejahatan akan marak dalam masyarakat itu. Akan tetapi seiring berjalannya waktu kejahatan juga ditimbulkan oleh kemakmuran. Untuk terus menekan agar tindak pidana tidak terus terulang memang harus dilakukan dengan berbagai macam cara baik dengan cara yang tegas maupun dengan penegakan hukum pidana yang bersifat represif maupun yang bersifat preventif.
\end{abstract}

Kata Kunci : Kejahatan, Hukum Pidana, Pemidanaan

\footnotetext{
*) Dosen Tetap Ilmu Hukum Jurusan Ahwal Syakhsiah STAI Miftahul Huda Al Azhar Citangkolo Kota Banjar.
} 


\section{PENDAHULUAN}

Bagi masyarakat Kejahatan kerap kali menimbulkan masalah, munculnya residivis, dan adanya kejahatan yang bersifat professional merupakan masalah pelik yang terus mendapat sorortan dan perhatian aparat penegak hukum. Kejahatan yang terjadi dalam masyarakat dan upaya pencegahannya terus menjadi perbincangan untuk dicarikan pemecahan pokok persoalan kejahatan itu.

Menurut hukum, kejahatan adalah perbuatan manusia yang bertentangan serta melanggar dengan apa yang sudah ditentukan dalam kaidah hukum. Ada banyak hal menyangkut masalah kejahatan, dan semua itu sangat erat kaitannya dengan perkembangan masyarakat itu sendiri dan bahkan menjadi bagian tersendiri dalam masyarakat. Seperti yang dikatakan oleh Sudarto bahwa kejahatan merupakan suatu gejala yang menyangkut setiap orang. Kejahatan berkisar mengenai bentuk yang ringan dan berat. Namun harus disadari bahwa yang melakukan kejahatan itu juga orang seperti kita semua dan disisi lain kejahatan harus terus ditanggulangi karena mendatangkan ketidak tentraman dalam masyarakat. Salah satu asas penting dalam masalah ini ialah "usaha-usaha mencegah kejahatan harus lebih diutamakan dari usaha memperbaiki para penjahat" (Soedjono Sukanto, 1976: 221).

George C Vold dalam sebagaimana dikutip oleh I.S. Susanto mengatakan bahwa mempelajari kejahatan terdapat persoalan rangkap, artinya bahwa kejahatan selalu menunjuk pada perbuatan manusia dan juga batasan-batasan atau pandangan masyarakat tentang apa yang diperbolehkan dan apa yang dilarang, apa yang baik dan apa yang buruk yang semua itu terdapat dalam undang-undang, kebiasaan dan adat istiadat (I.S. Susanto, 2011: 15).

Lain halnya dengan E Durkheim seorang pakar sosiologi menyatakan bahwa kejahatan bukan saja normal, dalam arti tidak ada masyarakat tanpa kejahatan, bahkan dia menambahkan bahwa kejahatan merupakan sesuatu yang diperlukan, sebab ciri masyarakat adalah "dinamis" dan perbuatan yang telah menggerakkan masyarakat tersebut pada mulanya seringkali disebut sebagai kejahatan, sebagai contoh dijatuhinya hukuman mati terhdap Galileo-Galilea atas buah pikirannya (I.S. Susanto, 2011: 15).

Dalam sebuah wawancara Pakar Tindak Pidana Pencucian Uang dari Universitas Trisakti, Yenti Garnasih memberikan pandangannya, bahwa hukuman Bui dan Denda dinilai tak membuat jera. Tindak kejahatan malah terus berulang 
apalagi praktek korupsi yang tetap marak, menurut pandangan Yenti Garnisih dalam kondisi ini masyarakat dianggap tak mampu memberikan sanksi sosial bagi para pelaku kejahatan seperti halnya koruptor. Minimnya efek jera kepada para pelaku kejahatan itu, menyebabkan masyarakat masih menerima dengan luwes keberadaan mereka di lingkungannya. Masih menurut pandangan Yenti Garnisih penentuan sanksi untuk membuat efek jera bagi para pelaku kejahatan harus melibatkan tokoh agama, sosiolog, budayawan, agar terjadi keteraturan sosial di tengah masyarakat (Https://Www.Cnnindonesia.Com/Nasional/20141002160343-12-5086/Bui-Dan-

\section{Denda-Tak-Membuat-Jera)}

Proses hukum yang selama ini telah berjalan atas penentuan hukuman yang ditimpakan kepada penjahat tidak juga memberikan efek jera kepada para pelakunya, hal ini dapat dilihat dengan adanya residivis kambuhan untuk kasuskasus pidana tertentu, bahkan untuk kasus yang menyedot perhatian publik pun seperti kasus korupsi meski para koruptor telah dipidana dengan hukuman maksimal namun tindak pidana ini seolah tidak pernah surut. Pertanyaannya Kenapa Sanksi Pidana maksimal tidak membuat Jera?.

Untuk menjawab hal itu perlu kiranya ada satu pemahaman mengenai masalah kejahatan yang terjadi dalam masyarakat dan upaya pencegahannya yang tidak saja dipecahkan melalui proses hukum, tetapi juga melalui pemahaman tingkah laku yang menyimpang dari perbuatan si penjahat itu sendiri. Terus berulangnya sebuah tindak kejahatan, membuat masyarakat seolah tatanan sosial di masyarakat tidak teratur, apalagi kondisi sosial budaya atau culture masyarakat sangat mempengaruhi bekerjanya sistem hokum berhubungan langsung dengan lingkungan, pekerjaan, profesi, dan lainnya. Kriminalitas itu adalah suatu hasil interaksi karena adanya interrelasi antara yang ada dan saling mempengaruhi. masalah kriminalitas sebagai suatu kenyataan sosial tidak berdiri sendiri (Ninik Widiyanti Dan Panji Anoraga, 1978 :149).

\section{TINJAUAN PUSTAKA}

\subsection{Hukum dan Manusia}

Manusia dan Hukum merupakan dua hal yang tidak dapat dipisahkan dalam kehidupan dunia ini, hal ini dikarenakan tanpa sebuah hukum yang mengatur tingkah laku manusia maka akan terjadi kekacauan di dalam kehidupan manusia (masyarakat), sifat bawaan manusia yang selalu ingin menang sendiri (atau yang 
lebih dikenal dengan istilah homo homini lupus), dan egois harus ditata dan diatur sedemikian rupa oleh hukum tanpa kecuali agar tidak melanggar hak orang lain (Handri Raharjo, 2016: 1).

Setiap manusia mempunyai kepentingan, Sudikno Mertokusumo sebagaimana dikutip oleh Handri Rahardjo (2016: 15) memaknai kepentingan sebagai:

Suatu tuntutan perorangan atau kelompok yang diharapkan untuk dipenuhi, untuk melindungi kepentingan manusia didalam masyarakat terdapat beberapa kaidah sosial, yaitu kaidah kepercayaan atau keagamaan, kaidah kesusilaan, kaidah sopan santun atau adat, dan kaidah hukum.

Dengan demikian maka, secara umum sebuah kaidah atau norma (hukum) pada hakikatnya merupakan patokan, panduan, dan pedoman bagi manusia untuk hidup dan bertingkah laku dalam kehidupan bermasyarakat (Handri Rahardjo, 2016: 15).

Tujuan hukum negara Republik Indonesia menurut hukum positif tertuang dalam alinea keempat Undang-Undang Dasar Republik Tahun 1945. Hukum mempertahankan perdamaian dengan menimbang kepentingan-kepentingan yang saling bertentangan secara teliti dan mengadakan keseimbangan diantaranya. Hukum hanya dapat mencapai tujuan mengatur pergaulan hidup secara damai jika ia menuju peraturan yang adil, artinya didalam peraturan itu terdapat keseimbangan antara kepentingan-kepentingan yang dilindungi sehingga menjamin orang memperoleh sebanyak mungkin apa yang menjadi bagiannya. Dengan demikian maka tujuan hokum pada intinya adalah memberikan keadilan, kepastian dan kemanfaatan (Handri Rahardjo, 2016: 10-11).

\subsection{Pidana Dan Pemidanaan}

Istilah "Hukuman" berasal dari kata "straf", menurut Mulyatno, jika "straf" diartikan sebagai Hukuman maka "strafrecht" diartikan "Hukuman-hukuman". Sudarto menyatakan bahwa istilah "Hukuman" kadang-kadang digunakan untuk pengganti perkataan "straf", namun menurutnya istilah "Pidana" lebih baik daripada "Hukuman" (Muladi Dan Barda Nawawi Arief, 2010: 1-2).

Istilah hukuman merupakan istilah umum dan konvensional, dapat mempunyai arti yang luas dan berkonotasi dengan bidang yang cukup luas. Oleh karena pidana merupakan istilah yang lebih khusus maka perlu ada pembatasan pengertian makna sentral yang dapat menunjukkan ciri-ciri dan sifatnya yang khas, untuk memberikan 
gambaran berikut ini beberapa pendapat atau definsi sarjana mengenai "Pidana" (Muladi Dan Barda Nawawi Arief, 2010: 2-4).

\section{Sudarto}

Yang dimaksud Pidana adalah penderitaan yang sengaja dibebankan kepada orang yang melakukan perbuatan yang memenuhi syarat-syarat tertentu

\section{Alf Ross}

Punishment is that social response which :

a. Occurs where there is violation of a legal rule ;

b. Is imposed and carried out by authorized person on behalf of the legal order to which the violated rule belong;

c. Involves suffering or at least other consequences normally considered unpleasant

d. Expresses disapproval of the violator

\section{Black's Law Dictionary}

"Punishment" adalah any fine, penalty or confinement inflicted upon a person by authority of the law and judgement and sentenceof a court for some crime or offence committed by him, or for his omissionof a duty enjoined by law

Dari berbagai definisi tersebut dapat diambil kesimpulan bahwa pidana mengandung unsur-unsur atau ciri-ciri sebagai berikut (Muladi Dan Barda Nawawi Arief, 2010: 4) :

1. Pidana itu pada hakekatnya merupakan suatu pengenaan penderitaan atau nestapa atau akibat-akibat lain yang tidak menyenangkan;

2. Pidana itu diberikan dengan sengajaoleh orang atau badan yang mempunyai kekuasaan (oleh yang berwenang);

3. Pidana itu dikenakan kepada seseorang yang telah melakukan tindak pidana menurut undang-undang.

Kejahatan telah menjadi fenomena yang universal, artinya tidak ada masyarakat tanpa kejahatan. Pada mulanya kejahatan disebabkan oleh faktor kemiskinan, dengan demikian dalam masyarakat yang mengalami kekurangan sumber daya alam, kejahatan akan marak dalam masyarakat itu. Akan tetapi seiring berjalannya waktu kejahatan juga ditimbulkan oleh kemakmuran, kejahatan korupsi misalnya, korupsi marak bukan karena pelakunya miskin, mereka pada umumnya secara ekonomis telah mapan tetapi kesempatan dan kebutuhan mendesak pelaku melakukan hal itu (M. Ali Zaidan, 2016: 2).

Dengan mengutip pandangan Frank Tannembaum, J.E. Sahetapy menyatakan bahwa kejahatan merupakan problema manusia, oleh karena itu di mana ada 
manusia, di sana pasti ada kejahatan, crime is eternal as eternal as society atau kejahatan abadi sebagaimana abadinya masyarakat (M. Ali Zaidan, 2016: 2).

Kejahatan merupakan fenomena social, yang keberadaan dan perkembangannya tidak dapat dipisahkan (disconnected) dari dan selalu berkaitan (interconnected) dengan masalah-masalah politik, ekonomi, social dan budaya masyarakat. Factor globalisasi multi dimensi ditunjang kemajuan teknologi kumunikasi, transportasi dan informasi modern sangat berpengaruh terhadap perkembangannya (Muladi dan Diah Sulistyani, 2016: 24)

Kebijakan penegakan hukum pidana memang selalu menjadi bagian dari kebijakan penggulangan criminal dalam rangka kebijakan perlindungan sosial, juga menjadi bagian integral dari kebijakan social untuk mencapai kesejahteraan masyarakat dalam menyelesaikan masalah-masalah sosial. Masyarakat adil makmur, dan tenteram (tertib) bisa tercapai dan dinikmati apabila para anggota masyarakat berperan aktif dan berperilaku dalam kehidupan sosialyang berwujud tertib sosial. Sedangkan tertib sosial merupakan interaksi diantara sesama warga dalam kelompok masyarakat yang harmonis, teratur dan tenteram. Suasana tertin sosial yang tidak muncul secara alamiakibat dari banyaknya tarik-menarik kepentingan, mengakibatkan tertib sosial itu harus diusahakan tercipta secara kontinu dalam masyarakat sebagai fondasi untuk mencapai kehidupan sosial ekonomi politik dan kebudayaan di dalam masyarakat (H. Moh. Hatta, 2010: 12)

Suasana tertib akan muncul dari adanya kehidupan yang didasarkan adanya semacam kontrak sosial atau kesepakatan dalam masyarakat yang dalam keadaan tertentu akan dapat menjadi kaidah hidup yang saling disepakati dan mengikat sebagai norma hidup bersama untuk menjadi pedoman hidup bersama secara teratur yang diiringi terbentuknya perangkat hokum. Peranan hukuml ambat laun akan semakin tampak yang kemudian dirumuskan secara tertulis dalam bentuk peraturan perundang-undangan maupun adat kebiasaan yang harus selalu dipatuhi untuk bersama-sama-sama menuju tertib hukum (H. Moh. Hatta, 2010: 12).

\section{HASIL PENELITIAN DAN PEMBAHASAN}

Sepanjang tahun 2018 jumlah kejadian atau peristiwa tindak pidana yang terjadi di tanah air cenderung mengalami penurunan hal ini setidaknya berdasarkan catatan dari Kepolisian Negara Republik Indonesia (Polri) dalam laporan akhir tahun yang di publikasikan ke mass media. Kapolri Jenderal Tito Karnavian dalam siaran Persnya Tanggal 27 Desember 2018 memaparkan jumlah kejadian kejahatan 
sepanjang 2018 menurun sebesar 21\% dibandingkan tahun 2017. Sementara penyelesaian perkara meningkat $7,3 \%$. Menurut data yang ia sampaikan, seluruh jenis kejahatan seperti konvensional, kejahatan transnasional, kejahatan terhadap kekayaan negara, dan kejahatan berimplikasi kontigensi, menurun pada 2018, kecuali kejahatan penganiayaan (konvensional crime) yang mengalami peningkatan (http://mediaindonesia.com/read/detail/206833-kapolri-sebut-jumlah-kasuskejahatan-di-2018-menurun)

Masih menurut Jenderal Tito Karnavian penyelesaian kasus kejahatan konvensional, kejahatan terhadap kekayaan negara, dan kejahatan berimplikasi kontingensi pada 2018 menurun dibandingkan 2017. Sedangkan penyelesaian kejahatan transnasional meningkat 39\%. Untuk kejahatan transnasional, penyelesaian perkara narkoba mengalami peningkatan pada 2018 dibandingkan tahun lalu. Jumlah kejahatan terkait narkoba pada 2018 meningkat sebesar 5\% atau dari 36.428 menjadi 38.316 kasus narkoba. Upaya penyelesaian perkara ini pun mengalami peningkatan $44 \%$, dari 26.641 kasus pada tahun sebelumnya menjadi 38.316 pada 2018. Sedangkan jumlah tersangka yang ditangkap sebanyak 49.079 orang atau menurun 22\% dibandingkan tahun 2017 (http://mediaindonesia.com/read/ detail/206833-kapolri-sebut-jumlah-kasus-kejahatan-di-2018-menurun).

Sementara untuk barang bukti narkoba yang paling banyak disita sepanjang 2018 berupa kokain, heroin, dan sabu meningkat signifikan. Perinciannya, kokain meningkat dari 68,47 gram menjadi 3.213,34 gram, heroin (204,37 gram menjadi 1.397,14 gram), dan Sabu (2,69 ton menjadi 4,01 ton). Untuk barang bukti ganja mengalami penurunan $77 \%$ (151 ton menjadi 34 ton) penurunan ini disebabkan oleh masifnya penegakan hukum di seluruh wilayah dalam beberapa tahun terakhir (http://mediaindonesia.com/read/detail/206833-kapolri-sebut-jumlah-kasuskejahatan-di-2018-menurun).

Penurunan angka kejahatan atau peristiwa tindak pidana juga terjadi di wilayah hukum Polda Jawa Barat, berdasarkan data yang di publikasikan oleh Kapolda jabar Irjend Agung Budi Maryoto melalui mass media tanggal 28 Desember 2018 tercacat Sepanjang tahun 2018, Penegakan Peraturan terhadap Pelanggaran disiplin Anggota Polri naik 6,16 \% (27 orang) dari 438 orang pada tahun 2017 Menjadi 465 orang, Pelanggaran tindak pidana anggota Tahun 2018 turun 53,85\% (14 orang) dari 26 orang pada tahun 2017 menjadi 12 orang pada tahun 2018, Pelanggaran kode etik anggota tahun 2018 turun 22,70 \% (19 orang) Dan dari 84 
orang pada tahun 2017 menjadi 65 orang pada tahun 2018, pemberhentian Tidak dengan Hormat (PTDH) pada tahun 2018 Naik 9,09\% (2 orang) dari 22 orang pada tahun 2017 menjadi 24 orang tahun 2018. Dari laporan Kamseltibcar Lantas Laka lantas pada tahun 2018 naik 0,89 \% (61 Kasus) dari 6865 Kasus pada tahun 2017 Menjadi 6.926 kasus pada tahun 2018, Korban Meninggal Dunia akibat laka Lantas 2018 turun menjadi 864\% (http://mediapatriot.co.id/2018/12/28/konferensi-pers-akhirtahun-mengenai-evaluasi-angka-kriminalitas-di-wilayah-hukum-polda-jabar-2018/).

Sedangkan data kriminalitas tindak pidana yang terjadi selama 2018 memperlihatkan ada penurunan 18,36\% (4.632 perkara) dimana pada tahun 2017 sebanyak 25.230 perkara sedangkan tahun 2018 Sebanyak 20.598 perkara. Tingkat kriminalitas tertinggi pada tahun 2018 berada di wilkum Polrestabes Bandung dengan jumlah Kasus 3.027 Kasus, kedua Polres bogor dengan jumlah Kasus dan ketiga polres karawang Sebanyak 1.877 Kasus. kasus kejahatan Konvensional tahun 2018 turun 29,50 \%(7.169 perkara) dimana pada tahun 2017 telah terjadi 24.298 perkara sementara tahun 2018 terjadi 17.129 perkara, pemberantasan kejahatan jalanan pencurian pemberatan tahun 2018 turun 33,78\%. Kejahatan Transnational terjadi diwilayah hukum polda Jabar meliputi: kasus Trafficking tahun 2018 turun 41,94 \% (26 perkara Dari 62 perkara pada tahun 2017 menjadi 36 perkara Ada tahun 2018, kasus UU ketenagakerjaan tahun 2018 turun 61,34\% (8 perkara) Dari 13 perkara ditahun 2017 menjadi 5 perkara pada tahun 2018, Kasus Penyulundupan Manusia pada tahun 2018 naik 100 \% (1 kasus), kejahatan Narkoba 2018 nail 0,82 \% (22 perkara) Dari 2,699 perkara pada tahun 2017 Menjadi 2.721 perkara tahun 2018 Dan jumlah tersangka yang ditangkap pada tahun 2018 turun 2,00 \% (67 orang) (http://mediapatriot.co.id/2018/12/28/konferensi-pers-akhir-tahun-mengenaievaluasi-angka-kriminalitas-di-wilayah-hukum-polda-jabar-2018/).

Sementara untuk kasus terhadap kekayaan negara tindak pidana korupsi 2018 naik 1,82\% Dan Polisi berhasil menyelamatkan uang negara 2018 Rp.9747.262.016. Dari Rp 14.169.294.938, jumlah kejahatan dunia maya/cyber Crime naik mencapai 46,88 \% (135) dari 288 kasus, dan kejahatan berimplikasi kontijensi pada tahun 20183 kasus, kejahatan diperairan pengungkapan kasus pidana diperairan turun 56,25\% (9 kasus) dari 16 kasus (http://mediapatriot.co.id/ 2018/12/28/konferensi-pers-akhir-tahun-mengenai-evaluasi-angka-kriminalitas-diwilayah-hukum-polda-jabar-2018/). 
Sedangkan angka kriminalitas di wilayah hokum polres banjar, tempat dimana peneliti berdomisili berdasarkan data resmi yang dirilis oleh Kapolres Banjar AKBP. Matrius dalam siaran persnya yang digelar pada 30 Desember 2018, terungkap peristiwa tindak pidana yang terjadi selama tahun 2018 menurun dibanding tahun 2017. Dari hasil analisa dan evaluasi singkat, angka penurunan tindak pidana tahun 2018 mencapai 34,6 persen atau sebanyak 133 perkara, sedangkan tahun 2017 sebanyak 179 perkara. Untuk Penyelesaian perkara tindak pidana tahun 2018 naik dari 133 perkara dapat diselesaikan 88 perkara atau 66,2 persen sedangkan pada tahun 2017 dari 179 perkara dapat diselesaikan 95 perkara atau 53,1 persen, sedangkan barang bukti yang sudah diamankan dari kasus kejahatan narkoba tahun 2018 di antaranya ganja sebanyak 84,49 gram, sabu sebanyak 20,87 gram, ganja sintetis sebanyak 9,88 gram, obat keras terbatas sebanyak 941 butir dan bahan berbahaya, seperti miras sebanyak 182 botol, tuak sebanyak 430 liter, ciu sebanyak 40 liter dan pangan $300 \mathrm{~kg} \mathrm{mi}$ berformalin, $4 \mathrm{~kg}$ soda air (https://www.radartasikmalaya.com/kapolres-banjar-mengklaim-angka-kriminalitasmenurun/)

Dari data yang diuraikan di atas, menurunnya angka kejahatan atau peristiwa tindak pidana menurut hemat peneliti lebih disebabkan oleh masifnya penegakan hukum yang dilakukan oleh aparat kepolisian, selain karena upaya penegakan hukum menurunnya angka kejahatan juga sedikit banyak dipengaruhi oleh programprogram aparat penegak hukum yang beroreintasi pada pencegahan yang dengan program preventif dan preemtif.

Untuk terus menekan agar tindak pidana tidak terus terulang memang harus dilakukan dengan berbagai macam cara baik dengan cara yang tegas maupun dengan penegakan hukum pidana yang bersifat represif maupun yang bersifat preventif. Karena pada hakikatnya hokum pidana bermaksud untuk melindungi setiap anggota masyarakat untuk mencapai jalan yang sejahtera lahir dan bathin.

Meski memiliki tujuan untuk melindungi, namun hokum pidana masih memiliki keterbatasan kemampuan dalam menanggulangi kejahatan yang terus berkembang di tengah masyarakat, hal ini sangat relevan dengan apa yang pernah dinyatakan oleh Sudarto sebagaimana dikutip oleh $\mathrm{H}$. Moh. Hatta yang menyatakan bahwa adalah ilusi belaka apabila kejahatandiharapkan lenyap di bumi ini ( $\mathrm{H}$. Moh. Hatta, 2010: 50). Kejahatan tersebut menjadi akibat logis dari perbuatan sosial yang 
menjurus negative dalam arti perbuatan devisiasi sosial dengan segala pertumbuhannya dalam urusan pathologi sosial.

Meningkat atau menurunnya tindak kejahatan di tengah masyarakat juga sangat dipengaruhi oleh efek perundang-undangan, efek suatu perundang-undangan di tengah masyarakat merupakan salah satu usaha untuk mengetahui apakah hukum benar-benar berfungsi atau berjalan atau tidak, sutau perundang-undangan yang baik belum cukup apabila hanya memenuhi persyaratan filosifis / ideologis dan yuridis saja, namun secara sosiologis peraturan tadi juga harus berlaku (Nina Herlina, 2008: 13)

Perkembangan kejahatan dan tindak pidana tidak bisa dilepaskan dari adanya perubahan sosial, begitupula naik dan turunnya angka kriminalitas yang terjadi ditengah masyarakat. Perubahan sosial dapat terjadi apabila suatu masyarakat sering mengadakan kontak dengan masyarakat lain. Sistem lapisan sosial yang terbuka, penduduk yang heterogen serta ketidakpuasan masyarakat terhadap bidang kehidupan tertentu dapat pula memperlancar perubahan social disamping juga dapat menjadi pemicu terjadinya sebuah tindak pidana (Nina Herlina, 2008: 58).

Meningkat dan menurunnya angka kejahatan juga sangat dipengaruhi oleh bagaimana aparat penegak hukum dalam memperlakukan para pelaku kejahatan, dalam system penyelenggaraan hokum pidana (criminal justice system) maka pidana menempati suatu posisi penting dan sentral, hal ini dikarenakan keputusan dalam hal pemidanaan akan mempunyai konsekuensi yang luas baik yang menyangkut langsung dengan pelaku tindak pidana maupun masyarakat secara luas, apalagi jika keputusan pidana tersebut dianggap tidak tepat maka akan menimbulkan reaksi yang "kontroversial" sebab kebenaran didalam hal ini sifatnya adalah relative tergantung dari mana kita memandangnya (Muladi Dan Barda Nawawi Arief, 2010: 52).

Tidak hanya di negara Indonesia, hampir di semua Negara didunia mengalami apa yang disebut sebagai "the disturbing disparity of sentencing" atau disparitas pidana, adapun pengertian dari disparitas pidana adalah penerapan pidana yang tidak samaterhadap tindak pidana yang sama (same offence)atau terhadap tindaktindak pidana yang sifat bahayanya dapat diperbandingkan (offence of comparable seriousness). Disparitas pemidanaan mempunyai dapak yang dalam karena di dalamnya terkandung pertimbangan konstitusional antara kebebasan individu dan hak Negara untuk memidana (Muladi Dan Barda Nawawi Arief, 2010: 52-53). 
Hukum pidana baik dalam pengertian "ius poenale" yang memuat larangan terhadap perbuatan yang bertentangan dengan hokum (onrecht) dan pengenaan suatu penderitaan kepada yang melanggar larangan tersebut, maupun sebagai "ius puniendi" yang merefleksikan hak Negara atau alat-alat perlengkapan Negara untuk mengancam dan mengenakan pidana atau tindakan terhadap perbuatan tertentu, merupakan hukum yang sanksinya dirasakan jauh lebih berat dibandingkan dengan sanksi bidang hukum lain seperti sanksi hukum perdata dan hukum administrasi. Sanksi hukum pidana baik pidana pokok berupa pidana mati, pidana denda, pidana penjara, pidana kurungan, pidana tambahan, dirasakan berat saat dijalani, tetapi disisi lain juga sudah dirasakan berat dan sudah mulai terjadi stigmatisasi social (Muladi dan Diah Sulistyani, 2016: 59).

Penderitaan berupa stigma social tidak hanya dirasakan oleh yang bersangkutan tetapi juga oleh keluarga dan orang-orang yang hidupnya bergantung padanya, oleh karena itu benar kiranya apa yang dikatakan oleh Von Liszt seperti yang dikutip oleh Muladi dan Diah Sulistyani, bahwa hokum pidana disatu pihak melindungi benda hokum manusia atau korporasi, namun dilain pihak justru dalam pelaksanaannya dilakukan dengan melanggar/melukai benda hukum itu sendiri. Atas dasar kenyataan ini timbul pemikiran agar hukum pidana digunakan secara hati-hati dan dioperasionalkan benar-benar sebagai obat yang terakhir (ultimum remedium) dan serta merta didayagunakan sebagai obat yang utama (primum remedium) (Muladi dan Diah Sulistyani, 2016: 60).

Pola pemidanaan yang salah dan cenderung berorientasi terhadap pembahasan dan penimpaan penderitaan terhadap pelaku kejahatan juga tidak jarang menjadi pemicu dan pendorong pelaku menjadi residivis, pemidanaan dengan pola seperti ini yang kita kenal dengan istilah teori pemidanaan Retributi. Pada teori retributif bahwa pemidanaan itu memiliki ciri-ciri sebagai berikut :

a. Tujuan pidana adalah semata-mata untuk pembalasan;

b. Pembalasan adalah tujuan utama dan didalamnya tidak mengandung sarana-sarana untuk tujuan lain, misalnya kesejahteraan masyarakat;

c. Kesalahan merupakan satu-satunya syarat adanya pidana;

d. Pidana harus disesuaikan dengan kesalahan si pelanggar;

e. Pidana melihat kebelakang ; ia merupakan pencelaan yang murni dan tujuannya tidak untuk memperbaiki , mendidik, atau memasyarakatlan kembali si pelanggar (Muladi dan Barda Nawawi Arief, 2010: 17). 
Dalam dekade terakhir muncul apa yang dinamakan keadilan restorative (restorative justice) sebagai kritik atas atas yang berlaku saat ini yaitu "retributive justice" yang bersifat "backward looking" dan melihat penerapan penderitaan terhadap si pelaku merupakan kewajiban. Masyarakat berada pada garis samping secara abstrak. Pidana merupakan bentuk pertanggungjawaban, tindak pidana dirumuskan dalam terminology teoritik, tanpa memiliki dimensi moral, sosial, dan ekonomi. Stigma tidak dapat dihapus, tidak ada dorongan untuk mengampuni. (Muladi dan Diah Sulistyani , 2016: 124-125)

Sebaliknya dalam konsep restorative justice diakui bahwa kejahatan sebagai konflik yang harus direkonsiliasikan, masyarakat yang harus menjadi fasilitator dalam proses restorative, peranan korban dan pelaku dalam tindak pidana diakui baik dalam permasalahan maupun penyelesaian hak-hak dan kebutuhan korban. Pelaku tindak pidana didorong untuk bertanggung jawab dan memutuskan yang paling baik, tindak pidana dipahami dalam konteks menyeluruh: moral, sosial, dan ekonomi (Muladi dan Diah Sulistyani , 2016: 125)

Untuk membuat tatanan yang terbit hokum merupakan instrumen yang dapat digunakan untuk mewujudkan hal itu, bahkan hukum merupakan gambaran dari tatanan yang ada dalam sebuah kelompok masyarakat, karena hokum dan masyarakat memiliki hubungan yang sangat erat. Friedrich Carl Von Savigny sebagaimana di kutip oleh Syarif Mappiasse (2015:22) menyatakan terdapat hubungan organic antara hokum dan watak karakter suatu bangsa, hukum hanyalah cerminan dari volkgeist, oleh karena itu hokum adat yang tumbuh dan berkembang dalam Rahim volkgeist harus dipandang sebagai hukum kehidupan sejati. Hukum sejati itu tidak dibuat tapi harus ditemukan, legislasi itu penting selama ia memiliki sifat deklaratif terhadap hukum sejati itu.

Berbeda dengan Savigny, Roscoe Paund seperti yang dikutip oleh Syarif Mappiasse (2015 : 23) Paund menyatakan bahwa hukum merupakan sarana rekayasa masyarakat (a tool of social engineering), menurut Paund, fungsi hukum yaitu sebagai alat untuk melakukan pembaruan masyarakat juga hokum sebagai alat pengontrol masyarakat, artinya hukum akan mempertahankan model sosial yang ada khususnya kehidupan social yang dianggap baik dan diterima oleh masyarakat.

Perspektif Paund bahwa hukum sebagai alat pembaruan masyarakat telah lama dianut di Indonesia, baik melalui perundang-undangan maupun melalui putusan hakim di Indonesia. Mochtar Kusumaatmadja memberikan pandangan dengan 
teorinya hukum pembangunan, yang memodifikasi teori Roscoe Paund (a tool of social engineering), menurut pandangan Mochtar Kusumaatmadja, hukum merupakan alat untuk memelihara ketertiban ditengah masyarakat, karenanya sifat dasar dari hukum adalah konservatif artinya bersifat memelihara dan mempertahankan apa yang telah tercapai, jadi semua hasil pembangunan harus dipelihara, dilindungi dan diamankan. Sifat manusia yang dinamis dan berubah dengan cepat sedangkan hukum tidak demikian, tetapi hukum harus membantu masyarakat dalam proses perubahan masyarakat (Syarif Mappiasse, 2015 : 24).

Pada hakekatnya penegakan hukum merupakan jaminan negara kepada warga negaranya untuk mendapatkan perlakuan yang adil baik dalam hal berkaitan dengan masalah hukum maupun kehidupan bernegara maupun masyarakat (Hibnu Nugroho, 2015: 48). Muladi seperti dikutip oleh Hibnu Nugroho berpendapat dalam proses penegakan hukum pidana, sebenarnya bukan dalam tahap aplikasi saja melainkan bisa tahap formulasi yaitu tahap penegakan hukum in abstacto oleh badan legislatif.

Robert B. Seidman (Esmi Warassih, 2011: 10) menyatakan bahwa basis bekerjanya hukum adalah masyarakat, maka hukum akan dipengaruhi oleh faktorfaktor atau kekuatan sosial mulai dari tahap pembuatan sampai dengan pemberlakuan. Kekuatan sosial akan berusaha masuk dalam setiap proses legislasi secara efektif dan efesien. Peraturan dikeluarkan diharapkan sesuai dengan keinginan, tetapi efek dari perturan tersebut tergantung dari kekuatan sosial seperti budaya hukumnya baik, maka hukum akan bekerja dengan baik pula, tetapi sebaliknya apabila kekuatannya berkurang atau tidak ada maka hukum tidak akan bisa berjalan. Karena masyarakat sebagai basis bekerjanya hukum. Konsep Bekerjanya Hukum menurut Seidman sebagaimana dilukiskan oleh Satjipto Rahardjo digambarkan dalam bagan dibawah ini (Esmi Warassih, 2011: 10) 


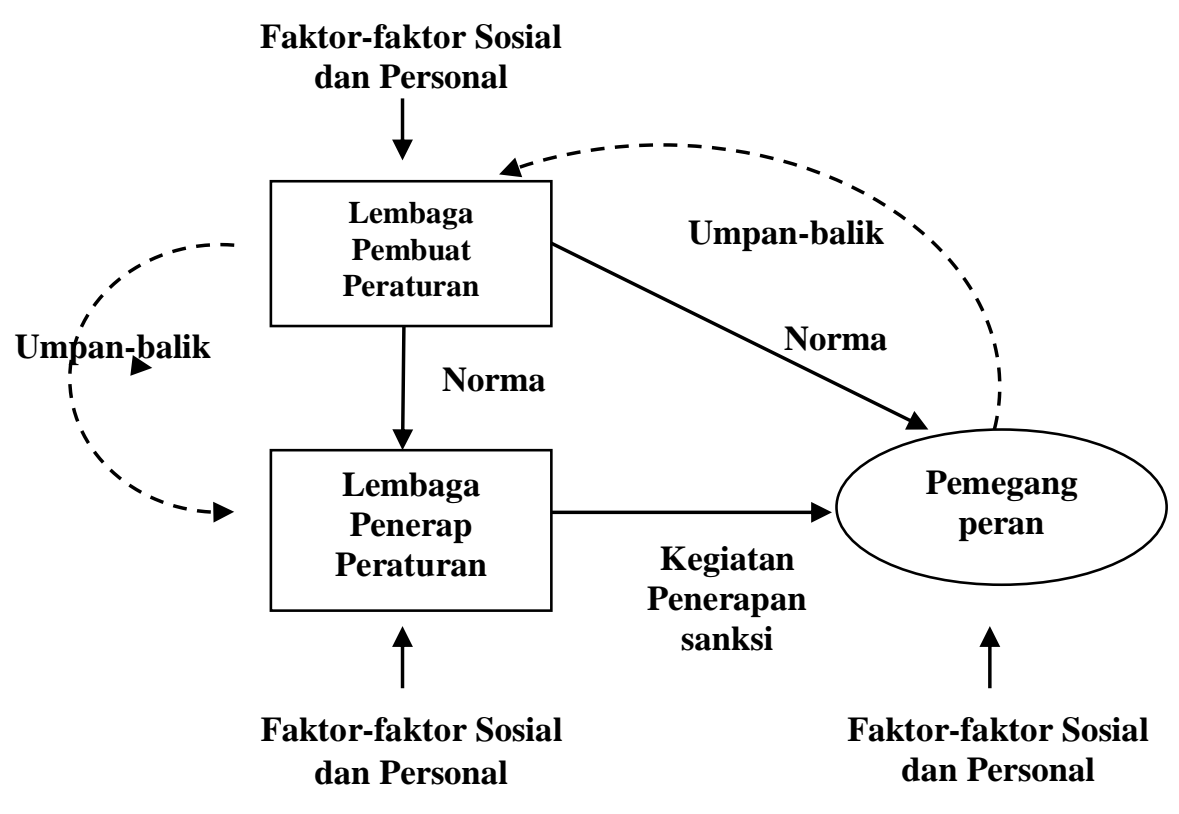

Berdasarkan model bekerjanya hukum tersebut, oleh Seidman dirumuskan beberapa pernyataan teoretis sebagai berikut :

1. Setiap peraturan hukum itu menunjukkan aturan-aturan tentang bagaimana seseorang pemegang peran diharapkan untuk bertindak;

2. Tindakan apa yang akan diambil oleh seseorang pemegang peran sebagai respons terhadap peraturan hukum, sangat tergantung dan dikendalikan oleh peraturan hukum yang berlaku, dari sanksi-sanksinya, dari aktivitas lembaga pelaksanaannya, serta dari seluruh kompleks kekuatan sosial, politik, dan lain sebagainya yang bekerja atas dirinya;

3. Tindakan apa yang akan diambil oleh lembaga pelaksana sebagai respons terhadap peraturan-peraturan hukum, sangat tergantung dan dikendalikan oleh peraturan hukum yang berlaku, dari sanksi-sanksinya, dan dari seluruh kompleks kekuatan sosial, politik, dan lain sebagainya yang bekerja atas dirinya, serta dari umpan balik yang datang dari pemegang peran dan birokrasi;

4. Tindakan apa yang akan diambil oleh lembaga pembuat undang-undang sebagai respons terhadap peraturan hukum, sangat tergantung dan dikendalikan oleh berfungsinya peraturan hukum yang berlaku, dari sanksisaksinya, dan dari seluruh kompleks kekuatan sosial, politik, dan lain sebagainya yang bekerja atas mereka, serta dari umpan balik yang datang dari pemegang peran dan birokrasi (Esmi Warassih, 2011:21). 
Sedangkan menurut Soerjono Soekanto (1993: 6) dalam upaya penegakan hukum ada faktor-faktor yang turut mempengaruhi, faktor-faktor tersebut adalah :

1. faktor hukumnya sendiri yakni undang-undang dalam arti materiil yang meliputi peraturan tertulis yang berlaku umum dan dibuat oleh penguasa pusat maupun daerah yang sah.

2. faktor penegak hukum, yakni pihak-pihak yang langsung berkecimpung dalam penegakan hukum yang bertugas dibidang-bidang kehakiman, kepolisian, kejaksaan, kepengacaraan dan pemasyarakatan.

3. faktor sarana atau fasilitas yang mendukung penegakan hukum antara lain sumber daya manusia (SDM) yang unggul karena memiliki pendidikan, kemahiran, dan keterampilan yang memadai, sarana berupa peralatan bantu yang tidak ketinggalan jaman, pendaaan yang memadai dan lain sebagainya.

4. faktor masyarakat, yakni lingkungan dimana hukum tersebut diberlakukan atau diterapkan, penegak hukum berasal dari masyarakat dan bertujuan untuk mencapai kedamaian dalam masyarakat. oleh karena itu dipandang dari sudut tertentu masyarakat dapat mempengaruhi penegakan hukum.

5. faktor budaya, yaitu sebagai hasil karsa, cipta, dan rasa yang didasarkan pada karsa manusia didalam pergaulan hidup, kebudayaan biasanya mencakup nilainilai yang mendasari hukum yang berlaku, nilai-nilai merupakan konsepsi abstrak, mengenai apa-apa yang dianggap baik dan apa yang dianggap buruk, nilai-nilai tersebut lazimnya merupakan pasangan nilai-nilai yang mencerminkan dua keadaan ekstrim yang harus di selesaikan.

Berdasarkan teori Robert B. Seidman di atas dapat diketahui bahwa, setiap peraturan hukum memberitahu tentang bagaimana seorang pemegang peranan (role occupant) itu diharapkan bertindak. Bagaimana seorang itu akan bertindak sebagai respons terhadap peraturan hukum merupakan fungsi-peraturan-peraturan yang ditujukan kepadanya, sanksi-sanksinya, aktivitas dari lembaga-lembaga pelaksana serta keseluruhan kompleks sosial, politik dan lain-lainnya mengenai dirinya.

Bagaimana lembaga-lembaga pelaksana itu akan bertindak sebagai respons terhadap peraturan hukum merupakan fungsi peraturan-peraturan hukum yang ditujukan kepada mereka, sanksi-sanksinya, keseluruhan kompleks kekuatan sosial, politik dan lain-lainnya yang mengenai diri mereka serta umpan balik yang datang dari pemegang peranan. Bagaimana para pembuat undang-undang itu akan bertindak juga merupakan fungsi peraturan-peraturan yang mengatur tingkah laku 
mereka, sanksi-sanksinya, keseluruhan kompleks kekuatan sosial, politik, ideologis dan lain-lainnya yang mengenai diri mereka serta umpan balik yang datang dari pemegang peran serta birokrasi.

\section{SIMPULAN DAN SARAN}

\subsection{Simpulan}

Terdapat hubungan segitiga yang sangat erat antara tindak kejahatan atau perbuatan pidana, masyarakat dan hukum, ketiganya saling mempengaruhi satu sama lainnya. Kejahatan ditengah masyarakat yang mengganggu ketertiban sosial masyarakat juga bersumber dari tengah masyarakat itu sendiri yang dipicu oleh perubahan sosial masyakat yang tidak seimbang, perubahan sosial akan sangat mempengaruhi sistem sosial suatu masyarakat, termasuk didalamnya nilai-nilai, sikap dan pola-pola perikelakuan di antara kelompok-kelompok masyarakat, perubahan-perubahan sosial yang terjadi pada salah satu lembaga kemasyarakatan dapat saja menjalan ke lembaga-lembaga lainnya, dan pada suatu perubahan di bidang tertentu akan mempengaruhi bidang-bidang yang lain.

Sementara hukum pidana sebagai sarana control (instrument) selalu terdapat perbedaan antara pola prilaku yang berlaku di masyarakat dengan pola perilaku yang dikehendaki oleh kaidah-kaidah hukum. Menekan kejahatan untuk mewujudkan ketertiban tidak semata-mata dilakukan dengan jalan pemidanaan yang bertujuan atau berorientasi pada penerapan penderitaan bagi pelakunya, ada cara lain yang dapat memberikan efek yang lebih bermanfaat dengan memberikan keseimbangan antara pelaku, korban dan peran aparatur Negara.

\subsection{Saran}

Menekan dan Pencegahan terhadap tindak pidana tidak hanya cukup dilakukan dengan memberikan pidana yang berat, oleh karena itu diperlukan Komitmen bersama dan kesatuan pandangan dari semua stake holder dalam arti luas terhadap bentuk pemidanaan, yakni bahwa tujuan pemidanaan pada hakekatnya merupakan gabungan dari masing-masing tujuan (Masyarakat, hukum, dan pranata hukum) yang tidak hanya bertujuan untuk membuat penderitaan pelakunya. Tanpa ada komitmen bersama untuk menyatukan pandangan tersebut maka akan sangat sulit menciptakan proses pemidanaan yang dapat memuaskan semua pihak. 


\section{DAFTAR PUSTAKA}

1. Literatur / Buku

Hatta, H. Moh. Kebijakan Politik Kriminal, Penegakan Hokum Dalam Ranga Penanggulangan Kejahatan, Pustaka Pelajar, Yogyakarta, 2010.

Herlina, Nina Sari Kuliah Sosiologi Hukum, Universitas Galuh, Ciamis, 2008.

Mappiasse, Syarif, Logika Hukum Pertimbangan Putusan Hakim, Prenadamedia Group, Jakarta, 2015.

Muladi Dan Barda Nawawi Arief, Teori-Teori Dan Kebijakan Pidana, PT. Alumni, Bandung, 2010.

Dan Diah Sulistyani, Kompleksitas Perkembangan Tindak Pidana Dan Kebijakan Criminal, Pt. Alumni, Bandung, 2016.

Nugroho, Hibnu, Penerapan Asas Pembuktian Terbalik Dalam Tindak Pidana Korupsi Di Kejaksaan Tinggi Jawa Tengah (Laporan Tahunan Fasilitasi Guru Besar), Unsoed, 2015.

Raharjo, Handri, Sistem Hukum Indonesia, Ketentuan-Ketentuan Hokum Indonesia Dan Hubungannya Dengan Hukum Internasional, Pustaka Yustisia, Yogyakarta, 2016.

Soekanto, Soerjono, Faktor-Faktor Yang Mempengaruhi Penegakan Hukum, PT. Raja Grafindo, Jakarta, 1993.

Sukanto, Soedjono, Penanggulangan Kejahatan (Crime Prevention), Bandung, 1976.

Susanto, I.S., Materi Kuliah Kriminologi, Fakultas Hukum Universitas Jenderal Soedirman, 2011.

Widiyanti, Ninik Dan Panji Anoraga, Perkembangan Kejahatan Dan Masalahnya, PT Hastama, Jakarta, 1978.

Warassih, Esmi, , Pranata Hukum Sebuah Telaah Sosiologis, PT. Suryandaru Utama, Semarang, 2011.

Zaidan, M Ali, Kebijakan Kriminal, Sinar Grafika, Jakarta, 2016.

2. Internet / Mass Media

- https:/Www.Cnnindonesia.Com/Nasional/20141002160343-12-5086/Bui-DanDenda-Tak-Membuat-Jera, Diakses Pada 12 Januari 2019 , Pukul 11.00 WIB

- http://mediaindonesia.com/read/detail/206833-kapolri-sebut-jumlah-kasuskejahatan-di-2018-menurun, diakses pada tanggal 13 Januari 2019 , pukul 08.00 WIB. 
- http://mediapatriot.co.id/2018/12/28/konferensi-pers-akhir-tahun-mengenaievaluasi-angka-kriminalitas-di-wilayah-hukum-polda-jabar-2018/, diakses pada tanggal 13 Januari 2019 , pukul 08.00 WIB.

- https://www.radartasikmalaya.com/kapolres-banjar-mengklaim-angkakriminalitas-menurun/, diakses pada tanggal 13 Januari 2019 , pukul 08.00 WIB. 